Belas, J., Kmecová, I., Cepel, M. (2020). Availability of human capital and the development of the public infrastructure in the context of business activities of SMEs. Administratie si Management Public, 34, 27-44. DOI: 10.24818/amp/2020.34-02

\title{
Availability of human capital and the development of the public infrastructure in the context of business activities of SMEs
}

\author{
Jaroslav BELAS ${ }^{1}$, Iveta KMECOVA ${ }^{2}$, Martin CEPEL ${ }^{3}$
}

\begin{abstract}
The paper's objective is to define significant technological factors in the areas of human capital availability and research and development affecting the quality of small and medium-sized enterprises (SMEs) and their business environment, and to quantify differences between the Czech Republic (CR) and the Slovak Republic (SR). Based on the objective, empirical research was conducted including data from 312 SMEs in the CR and 329 SMEs in the SR processed with the use of Chi-squared tests and Z-scores. The research showed differences in assessing defined technological factors between the CR and the SR, and also confirmed a low level of the assessed factors in both countries. Furthermore, overall satisfaction with the quality of secondary schools and universities is relatively low despite the fact that the research showed a higher level of satisfaction with the quality of university education in both countries. In the Czech Republic, entrepreneurs largely experience a shortage of skilled workforce, with this factor achieving the highest negative rating. The Slovak entrepreneurs most negatively assessed the level of state support of research and development. Moreover, the entrepreneurs' overall level of satisfaction with the research and development infrastructure is relatively low, since only $23.08 \%$ of the Czech and $13.68 \%$ of the Slovak entrepreneurs agreed that the infrastructure is well built in their respective country. Similar results were also obtained in assessing state support of research and development. At the same time, it was found that research and development results help the entrepreneurs only to a limited extent, and the entrepreneurs in both countries are not very optimistic about future development of their business activities.
\end{abstract}

Keywords: public sector, availability of human capital, research and development, small and medium-sized enterprises

JEL: E24, L26, O15, J81

DOI: $10.24818 / \mathrm{amp} / 2020.34-02$

${ }^{1}$ Professor, PhD., Tomas Bata University in Zlin, Faculty of Management and Economics, Zlín, Czech Republic; email: belas@utb.cz

$2 \mathrm{PhD}$., Institute of Technology and Business in Ceske Budejovice, Faculty of Corporate Strategy, České Budějovice, Czech Republic; email: kmecova@ mail.vstecb.cz

3 PhD., Paneuropean University in Bratislava, Faculty of Economics and Business; Slovakia; email: martin.cepel@paneurouni.com 


\section{Introduction}

"The business environment of the 21 st century is increasingly being characterized by uncertainty, hypercompetition and rapid technological change, which has made the primary challenge faced by business firms one of survival." (Al-Jinini et al., 2019). According to Korsakiene et al. (2017), global economic trends have been forcing SMEs to increase their productivity, expand into new markets, and adopt new technologies. The changing business context of SMEs requires to focus on their resources as the main factors, contributing to the competitive advantage in both local and international markets.

The global economic crisis could be seen as a thorough test of the state of business environment in individual countries. Companies that were prepared for the turbulence in the business environment were able to manage and can now benefit from day-to-day situations. Companies that underestimated the issue are being more intensely confronted with existential problems as different economic and financial positions of small and medium-sized enterprises are being created as well.

Small and medium-sized enterprises (SMEs) play an important role in the economic system. In this context, it is necessary for effective cooperation to exist between the private sector and the public sector, which can significantly contribute to a growing standard of living through economic growth in a given country.

Conorto (2014) points out the importance of the so-called technological factors in the process of developing quality business environment. The factors include availability of human capital and research and development (R\&D) infrastructure.

It may be stated that innovation processes in companies are directly associated with the above factors as well, as innovations are the basis of sustainable company growth. A large number of expert and research studies deal with innovations in SMEs, and according to the latest trends, small enterprises have been intensively innovating in relation to environmental changes, whereas medium-sized and large enterprises have been more oriented to their operational efficiency. In addition, innovations are directly related to $R \& D$ infrastructure whose level is also assessed through start-up activities. These are business initiatives with high growth and innovation potential being able to initiate and support smart and inclusive economic growth in the long term, and attract foreign investments (The Ministry of Economy of the Slovak Republic, 2019). This encourages development of high value-added sectors and employment of a skilled workforce whose shortage may be sensed in the Czech Republic (CR) and the Slovak Republic (SR).

The above facts motivated the authors to carry out their research thematically focused on human capital and R\&D infrastructure, where one may expect a positive impact on the growth of innovation activities and competitiveness of SMEs in the domestic and international context. 
The research originality consists in defining and quantifying important areas of human capital and R\&D infrastructure that affect SMEs and their business activities. The presented empirical research is aimed at identifying attitudes of entrepreneurs who employ people in the production process and are pushed towards innovation activities by their competition.

The paper's structure is as follows. In the introductory section, results of research studies in a given field are presented. In the next part, there is a definition of the research objective, used methodology and data in the empirical research conducted in the CR and the SR. Research results are presented and discussed in the third part, and the final part presents the main results.

\section{Literature review}

Several foreign research studies examine the impact of human capital and research infrastructure on SMEs progress. Despite a wide range of research topics, their comparative analysis is somewhat problematic. This is also due to the fact that the studies are heterogeneous in nature, influenced by different focuses of research teams, as well as by different conditions of performing research, geographic affiliation of examined companies, accessibility to external/internal data base, research sample selection processes, etc. Nevertheless, they do provide valuable insights when studying impacts of various determinants on human capital and detecting new infrastructure parameters in the context of SMEs emergence and development. Also, they provide valuable ideas for developing a comparative basis for economic benchmarks and subsequent research objectives.

According to Alay \& Jeppe (2013), human capital is the stock of knowledge and skills embodied in labour force, which is a result of education and work, and adds a certain value to the labour force. Gomezelj \& Antonic (2015) present results of their empirical research carried out among 173 Slovenian SMEs and state: "Firms with employees who nurture their knowledge and skills are more likely to have higher growth and profitability than organizations in which employees are lacking such characteristics." Irwin et al. (2018) identify the previously mentioned feature as a competitive advantage for a given company.

Moreover, human capital has a significant positive impact on strategic management of human resources leading to company prosperity and competitiveness (Alomari, 2019).

In a number of research studies, human capital is cited as a direct determinant of innovations within an enterprise.

In recent years, various research studies have addressed the methodological aspects of measuring innovation performance. For instance, Gavurova et al. (2019a) examined research and development ratios of EU28 by applying DEA (Data Envelopment Analysis) and eventually provided comparative output. In his study, Zizlavsky (2016) focused on measuring innovation performance in the Czech business environment. Having used four own surveys, his results show 
significant shortcomings in the current approaches to measuring innovation effectiveness. Šebestová \& Nováková (2015) searched for a suitable model of exploring innovation company behaviour as well as identifying investment impact on innovations and several strategic aspects in the Czech and Slovak business environment. Their results claim that the post-crisis period was characterized by a high degree of flexibility for companies to adapt to new business sustainability conditions. Other studies provide implication and dissemination lines oriented mainly to the macroeconomic sphere. For instance, Rusu \& Toderascu (2014) observe changes in corporate decision-making processes in relation to the current macroeconomic instability in the EU. They consider access to finance to be an important determinant for developing technological infrastructure and providing the necessary level of innovation performance, which would ensure development of companies and their survival in challenging competitive conditions. Guercio et al. (2019) examined main determinants of European SMEs related to demand and access to external sources of finance. They used data from extensive databases of the European Central Bank and the European Commission. Their study shows that more innovative companies have a higher need for external financial support, but have more limited access to it. Additionally, an interesting finding is the fact that differences in the characteristics of companies, such as their size, innovation activities, degree of research and development, etc., have a significant impact on the access and demand for external sources of finance. Similar differentiations of perspectives are used by several authors in their SMEs research, which makes it possible to detect various complementary causations and initiate multi-dimensional sectoral analyses. This has had an effect on changes in designing SMEs research in recent years and forming comparative research platforms. The innovation aspects are also related to the demand for an efficient and high-quality workforce, which reflects a quality of a given country's education system. Schools, which mostly belong to the public sector, play an important role in the process of developing quality human capital.

Furthermore, schools prepare graduates who are able to find employment in companies as well as in the business environment. Blesia et al. (2019) present a business model for university graduates to support entrepreneurship competencies. The proposed education model showed changes in students' attitudes, where selfconfidence was a decisive factor in entrepreneurship after completion of the studies.

Chamoutová et al. (2019) focused on labour market and education characteristics, as previously stated by the National Institute for Education in 2018, and confirmed that young people applying for university studies are interested in further education. In their research, Fajčíková \& Urbancová (2019) identify and evaluate factors affecting student motivation to higher education. The results identified several factors affecting the motivation and expectations of students, the most important being quality teaching staff.

According to Chamlutová et al. (2019), immediately after leaving their secondary schools, individuals applying for admission to the tertiary education in 
2017/18 make up 45\% of all applicants. The applicants also consist of people being already employed and having previous experience. In the Czech Republic, 24\% of all inhabitants aged 25-64 apply for the tertiary education, which is still below the European Union average (31\%).

It should also be noted that universities ought to prepare quality graduates who are able to find employment in research and development. Particular cooperation between academics in the area of preparing new courses for more quality university education plays a significant role (Newell \& Bain, 2019). In research and development, human resources represent one of the key parameters of scientific and research systems. Personal and professional qualities of human resources are the basis for intensity and quality of implementing science and research as well as the success of results in the process of implementing new findings into practice.

Other research, focused on specific analyses of entrepreneurship competencies and innovation activities of SMEs, was conducted by Lara \& SalasVallina (2017) who discuss qualifications of graduates necessary for their possible activities in entrepreneurship. The objective of their research was to examine the influence of entrepreneurship competencies on positive attitudes to work and support the ability to work. A manager should primarily be a professional, but also a person with developed innovation thinking (Gulhelme \& Flavio, 2017). Following the above, it could be stated that it is necessary to support the development of entrepreneurial and managerial competencies at schools, and to develop practical skills necessary for possible employability in companies and business sectors as well as in research and development.

A specific group of research explicitly linking education processes to labour market demand is comprised of studies examining aspects of financial literacy. It is the level of financial literacy that reflects the quality of entrepreneurship education (Kubak et al. 2019). A number of countries attach particular importance to financial literacy of the young population, as evidenced by various research studies (e.g. McGraw Hill Financial, 2015; Gavurová et al. 2019b; Rasoaisi \& Kalebe, 2015, Nano \& Cani, 2016 and others). The Communication on Financial Education mentions particular economic and social benefits of a higher level of financial literacy and the basic principles of financial education according to selected procedures (European Commission, 2007). In this context, it is appropriate to emphasize the importance of implementing financial literacy and its relation to the quality of entrepreneurship education at secondary schools and universities. This also makes it possible to evaluate an extent to which the state can prepare quality people for real practice and business.

Nowadays, more authors draw their attention to exploring the growing internationalization of business activities associated with human capital and innovation. According to Buzavaite and Korsakiene (2019), research on international entrepreneurship considers the human capital theory as a significant theory in explaining the internationalisation of SMEs. The authors state that international activities of companies require appropriate resources and 
competencies and also add that human capital appears to be an important resource impacting the identification and exploitation of international opportunities. Based on a survey by Dabic et al. (2019) involving 253 SMEs in Croatia, their results suggest that "the key dimensions of intellectual capital, innovation culture, and organisational climate are vital to a company's success and are strongly intercorrelated. Higher business performance is positively related to higher levels of both intellectual capital and innovation culture. In a study by Onkelinx et al. (2016), there is an analysis regarding the theory of SMEs internationalization and economic models of exporting in order to explore an effect of investments in employee human capital on labour productivity, and the role of labour productivity in SMEs internationalization. The findings indicate that "the employee human capital requirements of rapidly and gradually internationalizing SMEs are very different. Firms pursuing a rapid internationalization strategy need employees with high levels of education and training to increase their overall productivity. This is not the same as for those firms pursuing a slow internationalization strategy, where labour productivity is less critical."

Gomezel \& Smolcic (2016) analyzed correlations between intellectual capital and innovativeness as well as the influence of innovativeness on a company growth. The authors claim that "there exists a significant relationship between Human Capital and Innovation, between Social capital and Innovations and between Organisational capital and Innovation. The strong and positive relationship between innovativeness and growth presents the importance of innovativeness for company growth."

\section{Objective, methodology and data}

The paper's objective is to define significant technological factors in the areas of human capital availability and research and development affecting the quality of the SME business environment, and to quantify differences between the Czech Republic (CR) and the Slovak Republic (SR).

In view of the defined objective, survey-based research was conducted with the inclusion of enterprises operating in the SME segment. As regards the research, 312 enterprises in the CR and 329 enterprises in the SR were approached and data collection eventually took place in 2018. The Czech enterprises were randomly selected from the "Albertína" company database, whilst the Slovak enterprises were randomly selected from the "Cribis" database containing a list of enterprises, organizations, and entrepreneurs. The enterprises were approached via emails asking them to fill out an online questionnaire. The questionnaire was intended for business owners or top management (hereinafter entrepreneurs).

The structure of respondents within the CR was as follows - length (time period) of operating a business: 1-5 years (56 enterprises), 5-10 years (48 enterprises), more than 10 years (208 enterprises); size of business: up to 10 employees (258 micro-enterprises), up to 50 employees (43 small enterprises), up to 250 employees (11 medium-sized enterprises). 
The structure of respondents within the SR was as follows - length (time period) of operating a business: 1-5 years (104 enterprises), 5-10 years (78 enterprises), more than 10 years (147 enterprises); size of business: up to 10 employees (234 micro-enterprises), up to 50 employees (71 small enterprises), up to 250 employees ( 24 medium-sized enterprises).

Individual constructs were defined using the following statements:

TF1: Availability of human capital

TF11: Secondary schools provide high quality graduates who prove to be valuable assets for the business sector.

TF12: Secondary schools provide a sufficient number of high quality graduates for business needs.

TF13: Universities provide high quality graduates who prove to be valuable assets for the business sector.

TF14: There is a sufficient amount of qualified workforce on the job market that proves to be a valuable asset for the business sector.

TF2: Infrastructure in the area of research and development. my country.

TF21: The research and development infrastructure is well established in

TF22: State support of research and development in my country is at a good level.

TF23: Research and development results help entrepreneurs in my country.

TF24: There is a growing trend in the state support of research and development.

Furthermore, the following scientific hypotheses were defined:

H1: There are no statistically significant differences between the CR and the SR in the attitudes of entrepreneurs regarding the availability of human capital.

H1a: There are no statistically significant differences between the CR and the SR in the positive attitudes of entrepreneurs regarding the availability of human capital.

$\mathrm{H} 2$ : There are no statistically significant differences between the CR and the SR in the attitudes of entrepreneurs regarding research and development.

$\mathrm{H} 2 \mathrm{a}$ : There are no statistically significant differences between the CR and the SR in the positive attitudes of entrepreneurs regarding research and development.

To evaluate the defined hypotheses, the method of descriptive statistics (percentage, means), Chi-squared tests and the Z-score method were applied. Statistically significant differences between positive responses of the designated social groups were compared with the use of Pearson statistics at the significance level of 5\%. If a calculated p-value was lower than 5\%, the null hypothesis was rejected, and an alternative hypothesis was adopted. The calculations were made through software available on the Internet.

\section{Results and discussion}

The following tables show empirical research results and their statistical processing. 
Table 1. Evaluation of the TF11 factor in the Czech Republic (CR) and the Slovak Republic (SR)

\begin{tabular}{|c|c|c|c|}
\hline $\begin{array}{l}\text { TF11: Secondary schools provide high } \\
\text { quality graduates who prove to be } \\
\text { valuable assets for the business sector. }\end{array}$ & $\begin{array}{l}\text { CR } \\
312\end{array}$ & $\begin{array}{l}\text { SR } \\
329\end{array}$ & $\begin{array}{l}\text { Z-score } \\
\text { p-value }\end{array}$ \\
\hline 1. I fully agree & 1 & 4 & \\
\hline 2. I agree & 69 & 76 & \\
\hline The ratio of $1+2$ on the total number (in \%) & 22.44 & 24.32 & $-0.562 / 0.575^{*}$ \\
\hline 3. I take no position & 87 & 56 & \\
\hline 4. I disagree & 135 & 163 & \\
\hline 5. I fully disagree & 20 & 30 & \\
\hline The ratio of $4+5$ on the total number (in $\%$ ) & 49.68 & 58.66 & $-2.282 / 0.023 * *$ \\
\hline Chi-square/p-value & \multicolumn{3}{|c|}{ 13.047/0.011 } \\
\hline
\end{tabular}

(Source: Authors' calculations)

The above table shows that only $22.44 \%$ of the Czech and $24.32 \%$ of the Slovak entrepreneurs working in the SME segment agreed with the statement that secondary schools provide quality graduates for the business sector.

The Chi-square/p-value (0.011) confirmed statistically significant differences in the overall response structure of respondents from both countries.

The Z-Score/p-value (0.023) confirmed statistically significant differences in the respondents' negative responses. As opposed to the Czech entrepreneurs, the Slovak entrepreneurs more significantly disagreed with the above statement.

\section{Table 2. Evaluation of the TF12 factor in the Czech Republic (CR)} and the Slovak Republic (SR)

\begin{tabular}{|l|c|c|c|}
\hline $\begin{array}{l}\text { TF12: Secondary schools provide a } \\
\text { sufficient number of high quality } \\
\text { graduates for business needs. }\end{array}$ & $\begin{array}{c}\text { CR } \\
\mathbf{3 1 2}\end{array}$ & $\begin{array}{c}\text { SR } \\
\mathbf{3 2 9}\end{array}$ & $\begin{array}{l}\text { Z-score } \\
\text { p-value }\end{array}$ \\
\hline 1. I fully agree & 1 & 7 & \\
\hline 2. I agree & 56 & 61 & \\
\hline The ratio of 1+2 on the total number (in \%) & 18.27 & 20.67 & $-0.766 / 0.441$ \\
\hline 3. I take no position & 78 & 66 & \\
\hline 4. I disagree & 149 & 168 & \\
\hline 5. I fully disagree & 28 & 27 & $-0.651 / 0.516$ \\
\hline The ratio of 4+5 on the total number (in \%) & 56.73 & 59.27 & \multicolumn{2}{|c|}{$6.424 / 0.170$} \\
\hline Chi-square/p-value & \multicolumn{2}{|l|}{} \\
\hline
\end{tabular}

(Source: Authors' calculations)

It may be observed that only $18.27 \%$ of the Czech and $20.67 \%$ of the Slovak entrepreneurs agreed that secondary schools provide enough quality graduates for the needs of business practice. 
The Chi-square/p-value (0.170) confirmed no statistically significant differences in the overall response structure of respondents from both countries.

The Z-Score/p-values (0.441/0.516) confirmed no statistically significant differences in the respondents' positive or negative responses.

Table 3. Evaluation of the TF13 factor in the Czech Republic (CR) and the Slovak Republic (SR)

\begin{tabular}{|l|c|c|c|}
\hline $\begin{array}{l}\text { TF13: Universities provide high quality } \\
\text { graduates who prove to be valuable assets for } \\
\text { the business sector. }\end{array}$ & $\begin{array}{c}\text { CR } \\
\mathbf{3 1 2}\end{array}$ & $\begin{array}{c}\text { SR } \\
\mathbf{3 2 9}\end{array}$ & $\begin{array}{l}\text { Z-score } \\
\text { p-value }\end{array}$ \\
\hline 1. I fully agree & 3 & 4 & \\
\hline 2. I agree & 96 & 99 & \\
\hline The ratio of 1+2 on the total number (in \%) & 31.73 & 31.31 & $0.115 / 0.904$ \\
\hline 3. I take no position & 117 & 74 & \\
\hline 4. I disagree & 80 & 127 & \\
\hline 5. I fully disagree & 16 & 25 & \\
\hline The ratio of 4+5 on the total number (in \%) & $\mathbf{3 0 . 7 7}$ & $\mathbf{4 6 . 2 0}$ & $\mathbf{- 4 . 0 0 9 / < 0 . 0 0 1}$ \\
\hline Chi-square/p-value & \multicolumn{2}{|l|}{$\mathbf{2 2 . 0 8 1 / < 0 . 0 0 1}$} \\
\hline
\end{tabular}

(Source: Authors' calculations)

The research showed a better (though a relatively low) assessment of the quality of universities in both countries, as $31.73 \%$ of the Czech and $31.31 \%$ of the Slovak entrepreneurs agreed that universities provide quality graduates for the business sector.

The Chi-square/p-value $(<0.001)$ confirmed statistically significant differences in the overall response structure of respondents from both countries.

The Z-Score/p-value $(<0.001)$ confirmed statistically significant differences in the respondents' negative responses. In comparison with the Czech entrepreneurs, the Slovak entrepreneurs more significantly disagreed with the above statement.

Table 4. Evaluation of the TF14 factor in the Czech Republic (CR) and the Slovak Republic (SR)

\begin{tabular}{|l|c|c|c|}
\hline $\begin{array}{l}\text { TF14: There is a sufficient amount of qualified } \\
\text { workforce on the job market that proves } \\
\text { to be a valuable asset for the business sector. }\end{array}$ & $\begin{array}{c}\text { CR } \\
\mathbf{3 1 2}\end{array}$ & $\begin{array}{c}\text { SR } \\
\mathbf{3 2 9}\end{array}$ & $\begin{array}{l}\text { Z-score } \\
\text { p-value }\end{array}$ \\
\hline 1. I fully agree & 4 & 5 & \\
\hline 2. I agree & 49 & 92 & \\
\hline The ratio of 1+2 on the total number (in \%) & $\mathbf{1 6 . 9 9}$ & $\mathbf{2 9 . 4 8}$ & $\mathbf{- 3 . 7 3 5 / < 0 . 0 0 1}$ \\
\hline 3. I take no position & 53 & 47 & \\
\hline 4. I disagree & 150 & 145 & \\
\hline 5. I fully disagree & 56 & 40 & $\mathbf{5 6 3}$ \\
\hline The ratio of 4+5 on the total number (in \%) & $\mathbf{6 6 . 0 3}$ & $\mathbf{5 6 . 2 3}$ & $\mathbf{2 . 6 1 8 / 0 . 0 0 9}$ \\
\hline Chi-square/p-value & \multicolumn{3}{|c|}{} \\
\hline
\end{tabular}

(Source: Authors' calculations ) 
Entrepreneurs in the Czech Republic (66.03\%) strongly disagreed with the claim that there is enough qualified workforce on the market. The rate of disagreement in the SR was significantly lower ( $\mathrm{p}$-value $=0.009$ ).

The Chi-square/p-value $(<0.003)$ confirmed statistically significant differences in the overall response structure of respondents from both countries.

The Z-Score/p-values $((<0.001 / 0.009)$ confirmed statistically significant differences in the respondents' positive and negative responses. The Slovak entrepreneurs more significantly agreed with the above claim.

Table 5. Evaluation of the TF21 factor in the Czech Republic (CR) and the Slovak Republic (SR)

\begin{tabular}{|l|c|c|c|}
\hline TF21: The research and development & CR & SR & Z-score \\
infrastructure is well established in my country. & $\mathbf{3 1 2}$ & $\mathbf{3 2 9}$ & p-value \\
\hline 1. I fully agree & 5 & 6 & \\
\hline 2. I agree & 67 & 39 & \\
\hline The ratio of 1+2 on the total number (in \%) & $\mathbf{2 3 . 0 8}$ & $\mathbf{1 3 . 6 8}$ & $\mathbf{3 . 0 7 9 / 0 . 0 0 2}$ \\
\hline 3. I take no position & 167 & 89 & \\
\hline 4. I disagree & 62 & 158 & \\
\hline 5. I fully disagree & 11 & 37 & \\
\hline The ratio of 4+5 on the total number (in \%) & $\mathbf{2 3 . 4 0}$ & $\mathbf{5 9 . 2 7}$ & $\mathbf{- 9 . 2 0 4 / < 0 . 0 0 1}$ \\
\hline Chi-square/p-value & \multicolumn{3}{|c|}{$\mathbf{8 6 . 8 3 7 / < 0 . 0 0 1}$} \\
\hline
\end{tabular}

(Source: Authors' calculations)

As shown above, only $23.08 \%$ of the Czech and $13.68 \%$ of the Slovak entrepreneurs agreed with the statement that the $R \& D$ infrastructure is well built in their respective country.

The Chi-square/p-value $(<0.001)$ confirmed statistically significant differences in the overall response structure of respondents from both countries.

The Z-Score/p-values $(0.002 /<0.001)$ confirmed statistically significant differences in the respondents' positive and negative responses. The Slovak entrepreneurs more significantly disagreed with the above statement.

Table 6. Evaluation of the TF22 factor in the Czech Republic (CR) and the Slovak Republic (SR)

\begin{tabular}{|l|c|c|c|}
\hline $\begin{array}{l}\text { TF22: State support of research and } \\
\text { development in my country is at a good level. }\end{array}$ & $\begin{array}{c}\text { CR } \\
\mathbf{3 1 2}\end{array}$ & $\begin{array}{c}\text { SR } \\
\mathbf{3 2 9}\end{array}$ & $\begin{array}{c}\text { Z-score } \\
\text { p-value }\end{array}$ \\
\hline 1. I fully agree & 4 & 6 & \\
\hline 2. I agree & 61 & 51 & \\
\hline The ratio of 1+2 on the total number (in \%) & 20.83 & 17.33 & $1.131 / 0.258$ \\
\hline 3. I take no position & 167 & 76 & \\
\hline 4. I disagree & 67 & 152 & \\
\hline 5. I fully disagree & 13 & 44 & \\
\hline The ratio of 4+5 on the total number (in \%) & $\mathbf{2 5 . 6 4}$ & $\mathbf{5 9 . 5 7}$ & $\mathbf{- 8 . 6 7 2 / < 0 . 0 0 1}$ \\
\hline Chi-square/p-value & \multicolumn{3}{|c|}{$\mathbf{8 4 . 8 3 0 / < 0 . 0 0 1}$} \\
\hline
\end{tabular}

(Source: Authors' calculations) 
The assessment of state support in the area of research and development is relatively negative, since only $20.83 \%$ of the respondents in the Czech Republic and $17.33 \%$ of the respondents in the Slovak Republic agreed that the support is at a good level.

The Chi-square/p-value $(<0.001)$ confirmed statistically significant differences in the overall response structure of respondents from both countries.

The Z-Score/p-value $(<0.001)$ confirmed statistically significant differences in the respondents' negative responses. The Slovak entrepreneurs more significantly disagreed with the above statement.

Table 7. Evaluation of the TF23 factor in the Czech Republic (CR) and the Slovak Republic (SR)

\begin{tabular}{|l|c|c|c|}
\hline $\begin{array}{l}\text { TF23: Research and development results } \\
\text { help entrepreneurs in my country. }\end{array}$ & $\begin{array}{c}\text { CR } \\
\mathbf{3 1 2}\end{array}$ & $\begin{array}{c}\text { SR } \\
\mathbf{3 2 9}\end{array}$ & $\begin{array}{c}\text { Z-score } \\
\text { p-value }\end{array}$ \\
\hline 1. I fully agree & 12 & 6 & \\
\hline 2. I agree & 75 & 81 & \\
\hline The ratio of 1+2 on the total number (in \%) & 27.88 & 26.44 & $0.410 / 0.682$ \\
\hline 3. I take no position & 178 & 116 & \\
\hline 4. I disagree & 40 & 103 & \\
\hline 5. I fully disagree & 7 & 23 & \\
\hline The ratio of 4+5 on the total number (in \%) & $\mathbf{1 5 . 0 6}$ & $\mathbf{3 8 . 3 0}$ & $\mathbf{- 6 . 6 2 3 / < 0 . 0 0 1}$ \\
\hline Chi-square/p-value & \multicolumn{3}{|c|}{$\mathbf{5 1 . 1 7 9 / < 0 . 0 0 1}$} \\
\hline
\end{tabular}

(Source: Authors' calculations)

As may be seen, $27.88 \%$ of the Czech and $26.44 \%$ of the Slovak entrepreneurs agreed with the statement that results in the area of research and development help entrepreneurs. It is interesting that up to 57\% of the Czech entrepreneurs could not take a position on the statement.

The Chi-square/p-value $(<0.001)$ confirmed statistically significant differences in the overall response structure of respondents from both countries.

The Z-Score/p-value $(<0.001)$ confirmed statistically significant differences in the respondents' negative responses. The Slovak entrepreneurs more significantly disagreed with the above statement.

Table 8. Evaluation of the TF24 factor in the Czech Republic (CR) and the Slovak Republic (SR)

\begin{tabular}{|l|c|c|c|}
\hline $\begin{array}{l}\text { TF24: There is a growing trend in the state } \\
\text { support of research and development. }\end{array}$ & $\begin{array}{c}\text { CR } \\
\mathbf{3 1 2}\end{array}$ & $\begin{array}{c}\text { SR } \\
\mathbf{3 2 9}\end{array}$ & $\begin{array}{c}\text { Z-score } \\
\text { p-value }\end{array}$ \\
\hline 1. I fully agree & 3 & 7 & \\
\hline 2. I agree & 65 & 84 & \\
\hline The ratio of 1+2 on the total number (in \%) & 21.79 & 27.66 & $-1.718 / 0.085$ \\
\hline 3. I take no position & 176 & 132 & \\
\hline 4. I disagree & 54 & 84 & \\
\hline
\end{tabular}




\begin{tabular}{|l|c|c|c|}
\hline $\begin{array}{l}\text { TF24: There is a growing trend in the state } \\
\text { support of research and development. }\end{array}$ & $\begin{array}{c}\text { CR } \\
\mathbf{3 1 2}\end{array}$ & $\begin{array}{c}\text { SR } \\
\mathbf{3 2 9}\end{array}$ & $\begin{array}{c}\text { Z-score } \\
\text { p-value }\end{array}$ \\
\hline 5. I fully disagree & 14 & 22 & \\
\hline The ratio of 4+5 on the total number (in \%) & $\mathbf{2 1 . 7 9}$ & $\mathbf{3 2 . 2 2}$ & $\mathbf{- 2 . 9 6 6 / 0 . 0 0 3}$ \\
\hline Chi-square/p-value & \multicolumn{2}{|c|}{$\mathbf{1 8 . 1 7 0 / 0 . 0 0 1}$} \\
\hline
\end{tabular}

(Source: Authors' calculations)

The assessment of whether state support of research and development has an upward trend was not very positive, as $21.79 \%$ of the Czech and $27.66 \%$ of the Slovak entrepreneurs agreed with the statement.

The Chi-square/p-value (0.001) confirmed statistically significant differences in the overall response structure of respondents from both countries.

The Z-Score/p-value $(<0.003)$ confirmed statistically significant differences in the respondents' negative responses. The Slovak entrepreneurs more significantly disagreed with the above statement.

Table 9. Overall comparison of factors between the Czech Republic (CR) and the Slovak Republic (SR)

\begin{tabular}{|l|c|c|c|c|c|}
\hline Factor & SID & SID+ & SID- & $\begin{array}{c}\text { Better assessment } \\
\text { in the CR* }\end{array}$ & $\begin{array}{c}\text { Better assessment } \\
\text { in the SR* }\end{array}$ \\
\hline TF11 & yes & no & yes & yes & \\
\hline TF12 & no & no & no & yes & yes \\
\hline TF13 & yes & no & yes & yes & \\
\hline TF14 & yes & yes & yes & & \\
\hline TF21 & yes & yes & yes & yes & \\
\hline TF22 & yes & no & yes & yes & \\
\hline TF23 & yes & no & yes & yes & \\
\hline TF24 & yes & no & yes & yes & \\
\hline
\end{tabular}

Notes: SID denotes statistically significant differences in the overall response structure; SID+ denotes statistically significant differences in the entrepreneurs' positive responses; SID- denotes statistically significant differences in the entrepreneurs' negative responses;

* determines a percentage difference between the entrepreneurs' positive and negative responses in the CR and the SR. If the result is positive, yes will be entered,

$$
\text { e.g. } \mathrm{TF} 11=(22.44-24.32)-(49.68-58.66)=7.1(\mathrm{CR}: \text { yes })
$$

(Source: Authors' calculations)

\section{Evaluation of hypotheses:}

H1 was not confirmed;

H1 a was partially confirmed;

$\mathrm{H} 2$ was not confirmed;

$\mathrm{H} 2 \mathrm{a}$ was partially confirmed.

The empirical research results confirmed that the assessment of availability of human capital and the assessment of research and development are relatively negative in both of the countries. The average value of the entrepreneurs' positive 
attitudes regarding availability of human capital in the CR was $22.36 \%$, whereas the average value of negative responses was $50.80 \%$. In the SR, the average value of positive responses was 26.44 , whereas the average value of negative responses was $55.09 \%$.

Similar results were observed in the area of research and development. The average value of the entrepreneurs' positive attitudes in the CR was $23.39 \%$, whilst the average value of negative responses was $21.47 \%$. In the SR, the average value of positive responses was 21.28, whilst the average value of negative responses was $47.34 \%$. On assessing this factor, responses of those entrepreneurs who could not take a position on the statement played a significant role. Possible explanations may include a lack of relevant information, specifics of small business, a lack of interest in the above areas, etc.

The lowest value of agreement with the presented statements among the Czech entrepreneurs was recorded for the TF14 statement, i.e. There is a sufficient amount of qualified workforce on the job market that proves to be a valuable asset for the business sector. The Slovak entrepreneurs least agreed with the TF2 1 statement, i.e. The research and development infrastructure is well established in my country.

It may be argued that qualified workforce is based on a sufficient level of education, which particularly applies to young people. In order to have a successful transition from their schools to the labour market, young people not only need to be properly qualified, but also possess skills that the labour market currently needs. According to Chamoutová et al. (2019), in terms of employability and demands of the labour market, graduates mostly lack practical skills in their field. According to Vlková et al. (2019), students should not only learn and be able to reproduce the content acquired, but they should also understand what they have learnt and should be able to use the knowledge in practice in relation to Industry 4.0. It is necessary to support the development of competencies and digital literacy (Batko \& Rohlikova, 2018). Berkova et al. (2019) also recommend including practical subjects in the curriculum. Additionally, emphasis should be put on the development of professional skills as well as student-oriented training carried out by companies in the form of simulated professional environment in classrooms, with the reason being that in practice young people often fail to find work.

As for unemployment, it is currently very low in the Czech Republic due to positive economic development. The overall unemployment rate in the Czech Republic is even the lowest of all EU countries. According to the Labour Force Sample survey conducted by the Czech Statistical Office, the unemployment rate of young people in 2017 was $5.4 \%$. More specifically, the unemployment rate of young people with secondary education is between 5 and $7 \%$. Rates on the tertiary education graduates stand at $2.4 \%$ (for graduates with bachelor's degree) and $2.2 \%$ (for graduates with master's degree). Both rates are significantly lower in comparison with the secondary school graduates (Ulovec \& Vojtech, 2018).

When considering enterprises and their finance and innovation structure, small and medium-sized enterprises in the SR, as Ivanova (2017) remarks, 
generally have a difficult access to external sources of finance. This also applies to innovation funding whose biggest source comprises enterprise profits, as declared by $50 \%$ of enterprises in the SR. The author further adds that the access to external funding depends on the size of a given enterprise. Similar conclusions were reached by Hvolkova et al. (2019) researching and comparing innovation barriers in Slovakia in 2014 and 2017. The authors claim that in 2014 the barriers affecting company innovations in the most significant way included a lack of necessary sources within the companies researched and high costs of innovations. Other important factors also involved uncertain demand for new products and services, a lack of external sources, qualified employees on the market and suitable innovation partners. According to the authors, the lack of financial sources was "the most significant barrier to innovations for micro and small enterprises, while for medium-sized enterprises, it was the level of expected costs of innovations. Unsuitable state innovation policy was marked as the second most significant barrier for micro and small enterprises, while for medium-sized enterprises, it was the third most significant barrier." In 2017, "the surveyed micro enterprises suffered the most from a lack of internal financial sources for innovations (59.86\%), while viewing innovation costs as too high (38.73\%), and unsupportive state innovation policy (25.35\%). Apart from the lack of internal sources (46.34\%), small enterprises indicated high costs of innovation (48.78\%) and the lack of qualified employees $(48.78 \%$ ) as the two most important barriers. Innovation activities among medium-sized enterprises were influenced mostly by a low level of employees with necessary qualifications (52.94\%), high costs of innovation $(47.06 \%)$, and unsuitable state innovation policy (47.06\%)."

Janoskova \& Kral (2019) provide some interesting information on innovations. The authors conducted their research in the V4 countries and report that "all the Visegrad Group countries belong to a group of moderate innovators, with the summary innovation index values of these countries falling below the EU28 average. The Czech Republic has the best position of all the V4 countries, whereas Poland has the worst. Moreover, Poland, Slovakia, and Hungary reached the best results within the employment impact category. The Czech Republic showed the best results within the firm investments category." In this respect, Ivanova \& Cepel (2018) point out that Slovakia should focus on broadening the use of its innovative potential, especially by evaluating its level and relations within other sector policies.

Regarding the research presented in this paper, the entrepreneurs in both countries were not very optimistic about the overall cooperation of the private sector and the public sector. Only $17.9 \%$ of the entrepreneurs in the Czech Republic and $17.6 \%$ of the entrepreneurs in the Slovak Republic agreed that the private-public sector cooperation was at a good level. The quality of services provided by the public sector was assessed very critically in both countries, since only $10.3 \%$ of the Czech and $16.1 \%$ of the Slovak entrepreneurs think that the public sector provides quality service to entrepreneurs. An upward trend in the development of cooperation between the private sector and the public sector was 
indicated by $19.6 \%$ of the Czech and $32.2 \%$ of the Slovak entrepreneurs in the SME segment.

\section{Conclusions}

The paper's objective was to define significant technological factors in the areas of human capital availability and research and development affecting the quality of the SME business environment, and to quantify differences between the Czech Republic (CR) and the Slovak Republic (SR).

The research indicated particular differences in the factors' assessment between the CR and the SR and also confirmed the existence of a low level of the technological factors in both countries.

The overall satisfaction with the quality of secondary schools and universities is relatively low. The research showed a higher level of satisfaction with the quality of university education, and this factor also achieved the highest positive rating in both countries. The entrepreneurs intensively experience a lack of skilled workforce, with this factor reaching the highest negative assessment in the Czech Republic. The level of state support of research and development was assessed most negatively by the Slovak entrepreneurs.

The overall level of the entrepreneurs' satisfaction in terms of research and development infrastructure is relatively low, as only $23.08 \%$ of the Czech and $13.68 \%$ of the Slovak entrepreneurs agreed that the R\&D infrastructure is well built in their respective country. Similar results were also recorded in the assessment of state support of research and development. At the same time, it was found that research and development results help the entrepreneurs only to a limited extent, and the entrepreneurs in both countries are not very optimistic when assessing future development.

Although the research has certain limits, it may be assumed that it brought about interesting insights which can broaden discussions in the aforementioned areas.

\section{References}

Alay, K. J., Jeppe, H. J. (2013). Knowledge management practices in a public sector organisation: the role of leaders cognitives styles. Journal of the Academy of Marketing Science, 17(3), 349-351. https://doi.org/10.1108/JKM-11-2012 0358

Al-Jinini, D. K., Dahiyat, S. E., Bontis, N. (2019). Intellectual capital, entrepreneurial orientation, and technical innovation in small and medium-sized enterprises. Knowledge and Process Management, 26, 69-85. https://doi.org/10.1002/ kpm. 1593

Alomari, Z. S. (2019). Does human capital moderate the relationship between strategic thinking and strategic human resource management? Management Science Letters, 10(3), 565-574. 
Batko, J., Rohlikova, L. (2018). Educational robotics as a new chllenge for training preservice teachers. INTED Proceedings, 272-280.

Berkova, K., Krpalek, P., Krpalkova Krelova, K. (2019). Future economic professionals: development of practical skills and competencies in higher education from the point of view of international employers. Economic Annals-XXI, 176(3-4), 91-98.

Blesia, J. U., Lek, M., Ratang, W., Hutajulu, H. (2019). Developing an Entrepreneurship Model to Increase Students' Entrepreneurial Skills: an Action Research Project in a Higher Education Institution in Indonesia. Systemic Practise and Action Research. https://doi.org/10.1007/s11213-019-09506-8

Buzavaite, M., Korsakiene, R. (2019). Human Capital and the Internationalisation of SMEs: A Systemic Literature Review. Entrepreneurial Business and Economics Review, 7(3), 125-142. https://doi.org/10.15678/EBER.2019.070307

Conorto, R. et al. (2014). Analýza, monitor kvality podnikatel'ského prostredia $v$ SR a konkurencie schopnost' ekonomiky [Analysis, business environment quality monitor in the Slovak Republic and competitiveness of the economy]. Bratislava: Centrum vzdelávania MPSVR SR.

Dabic, M., Laznjak, J., Smallbone, D., Svarc, J. (2019). Intellectual capital, organisational climate, innovation culture, and SME performance: Evidence from Croatia. Journal of Small Business and Enterprise Development, 26(4), 522-544. https://doi.org/10.1108/JSBED-04-2018-0117

European Commission. (2007). Communication on Financial Education. Brussels: European Commission [online]. Available at: http://ec.europa.eu/finance/ finservices-retail/capability/index_en.htm (last accessed 6 December 2019)

Fajcikova, A., Urbancova, H. (2019). Factors Influencing Students' Motivation to Seek Higher Education - A Case Study at a State University in the Czech Republic. Sustainability, 11(17). https://doi.org/10.3390/su11174699

Francisco, J. L., Salas-Vallina, A. (2017). Managerial competencies, innovation and engagement in SMEs: The mediating role of organisational learning. Journal of Business Research, 79, 153-155.

Gavurova, B., Halaskova, M., Korony, S. (2019a). Research and development indicators of EU28 countries from viewpoint of super-efficiency DEA analysis. Acta Universitatis Agriculturae et Silviculturae Mendelianae Brunensis, 67(1), 225242. https://doi.org/10.11118/ actaun201967010225

Gavurova, B., Kubak, M., Huculova, E., Popadakova, D., Bilan, S. (2019b). Financial Literacy and Rationality of Youth in Slovakia. Transformations in Business \& Economics, 18(3), 43-53.

Gomezelj, O, D., Smolcic, J., D. (2016). The influence of intellectual capital on innovativeness and growth in tourism SMEs: empirical evidence from Slovenia and Croatia. Economic Research-Ekonomska Istraživanja, 29(1), 1075-1090. https://doi.org/10.1080/1331677X.2016.1211946

Gomezelj, O, D., Antonic, B. (2015). Employees' knowledge determinants in SMEs: The case of Slovenia. Journal of Business Economics and Management, 16(2), 422-444. https://doi.org/10.3846/16111699.2012.734326 
Guercio, M. B., Martinez, L. B., Bariviera, A. F. (2019). SME Steeplechase: When Obtaining Money Is Harder Than Innovating. International Journal of Financial Studies, 7(2). https://doi.org/10.3390/ijfs7020025

Gulherme, T., Flavio, F. (2007). Implementation of lean manufacturing and situational leadership styles an empirical study. Leadership and Organisation Development, 38(7), 948-59. https://doi.org/10.1108/LODJ-07-2016-0165

Hvolkova, L., Klement, L., Klementova, V., Kovalova, M. (2019). Barriers Hindering Innovations in Small and Medium-Sized Enterprises. Journal of Competitiveness, 11(2), 51-67. https://doi.org/10.7441/ joc.2019.02.04

Chamoutova, D., Klenka, D., Koucky, J., Trhlikova, J., Ulovec, M., Vojtech, J. (2019). Uplatnéní absolventů škol na trhu práce - 2018 [Employment of school graduates on the labor market - 2018]. Prague: National Institute for Education, School Counseling and Continuing Education Facility [online]. Available at: http://www.nuv.cz/vystupy/uplatneni-absolventu-skol-na-trhu-prace-2018 (last accessed 9 December 2019)

Chi-Square Test Calculator. (2019). Social Science Statistics [online]. Available at: https://www.socscistatistics.com/tests/chisquare2/default2.aspx (last accessed 11 December 2019)

Irwin, K. C., Landay, K. M., Aaron, J. R., McDowell, W.C., Marino, L. D., Geho, P. R. (2018). Entrepreneurial orientation (EO) and human resources outsourcing (HRO): A "HERO" combination for SME performance. Journal of Business Research, 90, 134-140.

Ivanová, E., Čepel, M. (2018). The Impact of Innovation Performance on the Competitiveness of the Visegrad 4 Conutries. Journal of Competitiveness, 10(1), 54-72. https://doi.org/10.7441/joc.2018.01.04

Ivanová, E. (2017). Barriers to the development of SMEs in the Slovak Republic. Oeconomia Copernicana, 8(2), 255-272. https://doi.org/10.24136/oc.v8i2.16

Janoskova, K., Kral, P. (2019). An In-Depth Analysis of the Summary Innovation Index in the V4 Countries. Journal of Competitiveness, 11(2), 68-83. https://doi.org/ 10.7441/joc.2019.02.05

Korsakiene, K., Liucvaitiene, A., Buzavaite, M., Simelyte, A. (2017). Intellectual capital as a driving force of internationalization: a case of Lithuanian SMEs. Entrepreneurship and Sustainability Issues, 4(4), 502-515. https://doi.org/ 10.9770/jesi.2017.4.4(8)

Kubak, M., Gavurova, B., Drotar, G. (2019). On the technical efficiency and productivity changes development in Slovakian institutions of higher education 2005-2015: Malmquist index approach. Transformations in Business and Economics, 18(2), 215-236.

Lara, F. J., Salas-Vallina, A. (2017). Managerial competencies, innovation and engagement in SMEs: The mediating role of organisational learning. Scerince Direct. Journal of Business Research, 79, 152-154. https://doi.org/10.1016/j.jbusres.2017.06.002

McGraw Hill Financial. (2015). Global Financial Literacy [online]. Available at: https://www.mhfi.com/corporate-responsibility/global-financial-literacy-survey? keyfindings (last accessed 8 December 2019) 
Ministerstvo hospodárstva SR. (2019). Stratégia výskumu a inovácií pre inteligentnú špecializáciu [Research and innovation strategy for smart specialization]. Ministry of Economy of the Slovak Republic [online]. Available at: https://www.mhsr.sk/inovacie/strategie-a-politiky/strategie-vyskumu-a-inovaciipre-inteligentnu-specializaciu (last accessed 9 December 2019)

Nano, D., Cani, S. (2016). The Differences in Students' Financial Literacy based on Financial Education. Academicus - International Scientific Journal, https://doi.org/10.7910/DVN/4WU8KP

Newell, C., Bain, A. (2019). Academics' perceptions of collaboration in higher education course design. Higher Education Research \& Development, https://doi.org/ 10.1080/07294360.2019.1690431

Onkelinx, J., Manolova, T. S., Edelman, L. F. (2016). The human factor: Investments in employee human capital, productivity, and SME internationalization. Journal of International Management, 22, 351-364.

Rasoaisi, L., Kalebe, K., M. (2015). Determinants of financial literacy among The National University of Lesotho students. Asian Economic and Financial Review, 5(9), 1050-1060. https://doi.org/10.18488/journal.aefr/2015.5.9/102.9.1050.1060

Rusu V., D., Toderascu, C. (2014). Enterprise Financing in the Context of Macroeconomic Instability. Evidence from CEE Countries. Procedia Economics and Finance, 15, 730-737. https://doi.org/10.1016/S2212-5671(14)00440-7

Šebestová, J., Nowáková, K. (2015). Innovation spirit evaluation within service organizations: the case of the Czech Republic. Procedia - Social and Behavioral Sciences, 181. https://doi.org/10.1016/j.sbspro.2015.04.885

Ulovec, M., Vojtech, J. (2018). Nezaměstnanost absolventů škol se středním a vyšším odborným vzdéláním - 2018 [Unemployment of secondary school and university graduates - 2018]. Prague: National Institute for Education, School Counseling and Continuing Education Facility.

Vlkova, I., Miklosikova, M., Malcik, M. (2018). Misconceptions in education of physics among Czech secondary school graduates. INTED Proceedings, 1057-1061.

Zizlavsky, O. (2016). Innovation performance measurement: Research into Czech business practice. Ekonomska Istraživanja [Economic Research], 29(1), 816-838. https://doi.rog/10.1080/1331677X.2016.1235983

Zscore calculator. (2019). Social Science Statistics [online]. Available at: http://www.socscistatistics.com/tests/ztest/Default2.aspx (last accessed 11 December 2019) 